\title{
EPIDEMIJE KUGE U DUBROVAČKOM ZALEĐU TIJEKOM 17., 18. I 19. STOLJEĆA I PROTUEPIDEMIJSKE MJERE NA DUBROVAČKOJ GRANICI*
}

\author{
Marinko MARIĆ \\ Sveučilište u Dubrovniku \\ Studij Povijest Jadrana i Mediterana \\ Dubrovnik, Hrvatska
}

\author{
UDK: 616-036.22(497.5 Dubrovnik) \\ DOI: $10.21857 /$ ypn4oc12n9 \\ Pregledni rad \\ Prihvaćeno:12. svibnja 2020.
}

U radu se donosi pregled epidemija kuge u dubrovačkom zaleđu tijekom 17., 18. i 19. stoljeća i njihove refleksije na dubrovačko područje. Na temelju rijetkih i šturih vrela te objavljene literature analiziraju se posljedice epidemija u zaleđu i načini kako se tamošnje stanovništvo borilo protiv epidemija kuge. Analizirane su i mjere i načini kako su se Dubrovčani branili od širenja tih epidemija te koje su protuepidemijske mjere poduzimali kako se zaraze ne bi proširile preko granice na njihovo područje. Na primjeru nekoliko slučajeva vidi se što su sve Dubrovčani poduzimali kako bi zarazu zaustavili na granici, $s$ obzirom na to da je ona skoro pa stalno prijetila da se $s$ područja Osmanskog Carstva proširi na područje Republike. U radu je poseban naglasak stavljen na ulogu Zdravstvenog ureda koji je u Dubrovniku osnovan još u 14. stoljeću te revolucionarne protuepidemijske mjere karantene, kao vrlo učinkovite mjere od širenja epidemija.

Ključne riječi: epidemije kuge, protukužne mjere, dubrovačko zaleđe, Dubrovnik.

\section{UVOD}

Dobri odnosi sa zaleđem bili su nužan uvjet opstanka za Dubrovnik kroz čitavu njegovu prošlost. Naslonjeno neposredno na dubrovački teritorij, zaleđe je Dubrovčanima bilo strateški važno područje pa su se tamošnje političke, gospodarske i socijalne prilike često odražavale i na prilike u Dubrovniku. I Dubrovčanima i stanovnicima iz zaleđa bilo je u interesu da se međusobne veze održavaju, jednima zbog sigurnosti trgovine, a drugima zbog tržišta, mogućnosti zapošljavanja i nalaženja utočišta. ${ }^{1}$ Zato je granica između zaleđa i Republike uglavnom bila propusna i protočna za tamošnje pogranično stanovništvo.

Važnost zaleđa za Dubrovnik očitovala se i u demografskom aspektu. Dubrovnik je stanovništvu iz zaleđa bio prvo odredište, ujedno i mjesto zbrinjavanja viška stanovništva u trenutcima kad su povoljna demografska

* Ovaj rad sufinancirala je Hrvatska zaklada za znanost projektom broj 5527.

1 Zdenka Janeković-Römer, Stranac u srednjovjekovnom Dubrovniku: Između prihvaćenosti i odbačenosti, Radovi Zavoda za hrvatsku povijest, sv. 26, Zagreb, 1993., 27 - 38. 
kretanja proizvodila višak koji tamošnji gospodarski resursi nisu mogli apsorbirati. S druge strane, useljavanja iz zaleđa značajno su pridonosila održavanju demografskog balansa dubrovačkog stanovništva. Dubrovčanima je zaleđe bilo "demografski rasadnik“ odakle su obnavljali stanovništvo i dobivali svježu radnu snagu koja im je uglavnom nedostajala. Radilo se prije svega o katoličkom stanovništvu, a od druge polovice 18. stoljeća i pravoslavnom.

Migracijski tokovi između zaleđa i Dubrovnika bili su stalni. Njihov intenzitet ovisio je uglavnom o socijalnom i ekonomskom stanju $s$ obje strane granice. $\mathrm{U}$ vrijeme nemira u zaleđu, primjerice za vrijeme Hercegovačkog ustanka 1875./1878., skoro svo tamošnje stanovništvo izbjeglo je na dubrovačko područje. U mirnodopsko vrijeme migracije su se odvijale ustaljenim procesom tako da je svježa radna snaga iz zaleđa dolazila na rad u Dubrovnik i tamo najčešće trajno ostajala. Pogotovo je to bilo izraženo nakon velikog potresa 1667. godine kada je Dubrovniku trebala brojna radna snaga u obnovi porušenog Grada.

Presudna važnost granice između Republike i zaleđa pokazala se krajem 17. stoljeća kad su Mlečani zauzećem dubrovačkog zaleđa, 1695., spojili svoj teritorij $\mathrm{u}$ dolini Neretve $s$ onim u Boki kotorskoj. Tim se činom nad Republikom „stegla mletačka omča“ koja je bitno otežala promet trgovačkom robom i dovela Dubrovčane u veoma ozbiljnu i tešku situaciju. Zaleđe je u to doba bilo predmetom političkih previranja između četiri strane: Dubrovačke Republike, Mlečana, Osmanskog Carstva i Austrije. Pitanje zaleđa konačno je riješeno Karlovačkim mirom 1699. godine na korist Dubrovčana, ponajviše nastojanjem dubrovačke diplomacije.

Mletačka „omča“ znatno je poremetila dotadašnje odnose stanovništva s obje strane granice. Naime, pogranično stanovništvo je, na određen način, ovisilo jedno o drugom. Njihovi međusobni odnosi bili su isprepleteni ovisnostima o materijalnim dobrima, poput mesa i žitarica s područja Osmanskog Carstva te vina, ulja i soli s dubrovačkog područja. Također, njihovi odnosi bili su isprepleteni i socijalnim mrežama, poput kumstava, rodbinskih odnosa i sl.

\section{EPIDEMIJE KUGE U DUBROVAČKOM ZALEĐU}

Uz sveopće siromaštvo, izoliranost, suše i poplave, epidemije zaraznih bolesti bile su čimbenik koji je često dovodio u pitanje opstanak stanovništva u dubrovačkom zaleđu. Kad bi se takve dvije ili više nevolja pojavile istodobno, onda je to predstavljalo katastrofu za tamošnje stanovništvo. Najsmrtonosnije nevolje bile su epidemije kuge. To je bila bolest koja je „sijala smrt, unosila 
strah i paniku, izazivala strepnju mnogih roditelja, gledajući dječje umiranje, promatrajući vlastito raspadanje“. 2 Najčešće se pojavljivala iznenada i tako isto, nakon određenog vremena, i završavala, bez ikakvog logičnog objašnjenja. Uzrečica koja je pratila pojavu kuge bila je „Fuge cito, longe et tarde revertere!“ (Bježi brzo, što dalje, a kasno se vraćaj). Čak su i pojedini ugledni liječnici toga doba govorili da „oni, koji predlažu za zaštitu od kuge druga sredstva osim bijega, ili su budale ili su varalice“. ${ }^{3}$ Koliko su posljedice takvih epidemija bile strašne može se iščitati primjerice i iz ljetopisa bosanskih franjevaca. Tako fra Stipan Margitić, opisujući epidemiju kuge i gladi nakon nje u Bosni 1690. godine, piše: „Kud god bi se makô, ležahu mrtvaci: nit se kopahu, nit imadijaše tko. Ljudi jiđahu resu liskovu, s drvja koru, vinovu lozu, pse, mačke. U Sarajevu izidoše dica mater mrtvu; u Banjoj Luci, koga bi obisili, obnoć bi ga gladni ljudi svega izili.“4

Sobzirom na nepostojanje organizirane zdravstvene zaštite u zaleđu, epidemije kuge bile su česte. Samo u 17. stoljeću bilo ih je skoro 20.5 Tako su epidemije kuge zabilježene 1613., 1615., 1618., 1622., 1625., 1627 - 1628., 1638., 1647., 1648., 1654., 1657., 1660. - 1661., 1667. - 1670., 1672. - 1674., 1677. - 1679., 1680., 1690. - 1694. te 1698. godine, međutim o njima i njihovim posljedicama dostupna vrela vrlo su rijetka i štura. ${ }^{6}$ Kuga je u zaleđu harala više puta i tijekom 18. stoljeća. Poznate su epidemije iz 1705., 1707., 1724., a posebno je bila katastrofalna ona od 1728. do 1733. godine. O toj epidemiji tadašnji upravitelj Trebinjsko-mrkanske biskupije, nadbiskup Marko Andrijašević, 1733. godine piše Propagandi u Rim i javlja kako je samo na području Župe Dubrave u Hercegovini od kuge umrlo 104 katolika. ${ }^{7}$ Najveća smrtnost bila je u gradu Stocu, o čemu svjedoči i pismo stolačkog kapetana Ismaila Šarića Dubrovčanima: „Ako budete pitali za bolest: dosleka je iz našeg Stoca izišlo veće od 300 mrtvaca. A sadara svaki dan izlazu po

2 Nenad VeKarić, Kuga u Čepikućama 1815/6. godine, u: Zbornik Dubrovačkog primorja i otoka, sv. 2, Zbornik radova, ur. Zdravko Bazdan, 1988., 135 - 139.

3 Vladimir BAzAla, Calendarium pestis (II), Acta historica medicinae pharmaciae veterinae, sv. 2, Beograd, 1962., $72-87$.

4 Robert Jolić, Zarazne bolesti u Hercegovini u doba turske vladavine, Hercegovina, sv. 1/26, Mostar, 2015., $187-213$.

5 Djuro Orlić, Dubrovačke vijesti o epidemijama u Bosni i Hercegovini u XVII vijeku, Gradja II, Sarajevo, 1956., $47-64$.

6 Bogumil HrabaK, Talasi kuge na bosanskohercegovačkom upravnom prostoru 1463 - 1800, Acta historica medicinae stomatologiae pharmaciae medicinae veterinae, sv. 29/1, Beograd, 1989., 19 - 36; Vesna Miović-Perić, Na razmedu. Osmansko-dubrovačka granica (1667-1806), Dubrovnik, 1997., 118.

7 Izvješće nadbiskupa Marka Andrijaševića iz 1733. godine, u: Milenko KrešIć, Odnosi katolika jugoistočne Hercegovine s muslimanima i pravoslavnima u vrijeme osmanske vladavine - Od osmanskoga zauzeća do Bečkoga kongresa (1482. - 1815.), Zagreb, 2008., 64 - 65. 
4 do 5 mrtvaca, a mi hvala Bogu doslieka živimo zdravo.“8 ${ }^{\text {Ta }}$ se kuga proširila i na čitavu Bosnu, a kasnije i na Dalmaciju. O njezinim posljedicama ljetopisac iz franjevačkog samostana u Kraljevoj Sutjesci zapisao je: „Ove se godine otrova sva Bosna od kuge; a počela je u Sarajevu i u Jajcu još godine prošaste to jest 1731 ... Što od ove kuge pomre, mučno je znat broj. Ovo znam da u velikih mistî kakono u Sarajevu, Mostaru, Banjoj Luci... na dan bi se po trista mrtaca kopalo.

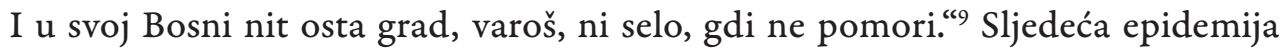
kuge koja je zabilježena je ona iz 1739. godine, zatim ona koja je trajala od 1741. do 1744. godine, kada je u Jajačkoj i u Sutješkoj župi umrlo oko 800 katolika, tj. trećina župljana u Jajcu i četvrtina u Sutjesci. ${ }^{10}$ Sljedeća epidemija trajala je od 1762. do 1765. godine. ${ }^{11}$ Nakon toga velika epidemija kuge bila je od 1781 . do 1785 . godine. Ona je ostavila strašne posljedice na tamošnje stanovništvo. ${ }^{12}$ U Bosni je tada umrlo preko 20000 katolika, a pravoslavnih, muslimana i Židova oko $100000 .{ }^{13}$ Ljetopisac fra Jako Baltić zapisao je da se kuga „raznijela po svoj Bosni i učinila strašan pomor... Zatim kuga kojoj nadiše [ime] oganj, po gradovim, osobito kod Turaka naglo moriaše. ${ }^{\text {"14 }}$ Ova se epidemija proširila i u Dalmaciju. Prenijeli su je useljenici iz Dalmacije koji su došli u Bosnu jer je te godine u Dalmaciji vladala velika glad. Oni su nakon pojave kuge pobjegli natrag u Dalmaciju, ali su sa sobom donijeli i kugu koja se tamo raširila.

Zadnja epidemija kuge u 18. stoljeću na prostoru dubrovačkog zaleđa bila je 1795. godine. ${ }^{15}$ Unatoč svim dubrovačkim protuepidemijskim mjerama, ona se brzo proširila i na dubrovačko područje. O tome u svom izvješću dubrovačkoj

8 Hamdija KAPIDŽıć, Stolac u XVIII vijeku, Slovo Gorčina, sv. 79, Stolac, 1997., 57 - 74.

9 Bono Benić, Ljetopis sutješkog samostana, Sarajevo, 1979., 115; Stipan Zlatović, Franovci države Presvetog Odkupitelja i hrvatski puk u Dalmaciji, Split, 1888., 221, 227, 229; R. Jolić, Zarazne bolesti u Hercegovini, 192.

10 Andrija Zirdum, Filip Lastrić Oćevac 1700-1783: prilog kulturnoj povijesti Bosne i Hercegovine, Zagreb, 1982., 12; Ruža RAdoš, Namjesnik bosanskog ejaleta Ali-paša Hekimoglu (1736 - 1748) i Dubrovačka Republika, Zagreb, 2017., 141.

${ }_{11}$ Zbog te epidemije trebinjsko-mrkanski biskup Anzelmo Katić nije mogao pohoditi biskupiju spomenute dvije godine. Vidi: Izvješće biskupa Anzelma Katića iz 1764. godine, u: M. KREŠIĆ, Odnosi katolika jugoistočne Hercegovine, 65.

12 Izvješće biskupa Anzelma Katića iz 1764. godine, u: M. KrešIć, Odnosi katolika jugoistočne Hercegovine, 65.

13 Jako BALtić, Andrija Zirdum, Godišnjak od dogadaja crkvenih, svjetskih i promine vrimena u Bosni, Sarajevo, 1991., 61 - 63; Mijo Vjenceslav Batinić, Djelovanje franjevaca u Bosni i Hercegovini za prvih šest viekova njihova boravka, Zagreb, 1881. - 1887., 151; R. Jolić, Zarazne bolesti u Hercegovini, 192.

14 J. Baltić, A. Zirdum, Godišnjak od dogadaja crkvenih, 63; R. Jolić, Zarazne bolesti u Hercegovini, 192.

15 Bogumil HrabaK, Kužne radnje u Bosni i Hercegovini 1463 - 1800, Istorijski zbornik, sv. 2., 1981., 22 - 24, 37; B. HrabaK, Talasi kuge, 19, 31. 
vladi svjedoči Đivo Karač koji piše kako je „na putu za Trebinje sreo dva Morlaka koja je pitao ima li kuge u Ljubinju. Oni su mu odgovorili potvrdno. U Trebinju je od prijatelja Osmanlije tražio odgovor na pitanje ima li kuge u tom gradu i dobio negativan odgovor. Od prijatelja je doznao da su neki Arnauti putovali iz Sarajeva preko Konjica za Nevesinje i da je tamo umro jedan od njih. Nastavili su prema Ljubinju pa je i tamo netko od njih preminuo." ${ }^{16}$ Nakon toga dubrovačke su vlasti u Ljubinje uputile Boža Brboru da to dodatno ispita. Brborin prijatelj iz Ljubinja Ahmet-aga Hadžić pričao mu je kako su „u gradu bila četvorica Arnauta koji su došli iz Bosne. Bili su u ove dvije kuće pa su sutradan pošli prema Nevesinju. Dva dana po odlasku Arnauta u Topalovića je umrlo jedno dijete, a u Ćuka dvoje djece. Dan kasnije oboljelo je troje djece i supruga od Topalovića. Sve je četvero umrlo tri dana kasnije. Potom su oboljeli i umrli Ćuk i njegova žena. Kao izvor kuge navodi se novac koji su Arnauti kao "bakšiš" dali djeci od Ćuka i Topalovića. Neki su ukućani iz ove dvije kuće pobjegli u brdo pa je Brbora Ćukovu kuću zatekao praznu, a u drugoj je kući, nakon što je sam pokopao svoje mrtve, bolestan ležao Topalović." ${ }^{17}$ U Ljubinju je nakon Brbore boravio i Nikola Kurtović koji je naveo kako je u dvije kuće ukupno umrlo jedanaest osoba. ${ }^{18}$

Početak 19. stoljeća donio je nove zdravstvene nevolje stanovništvu u zaleđu. U ljeto 1814. godine epidemija kuge zahvatila je čitavu Bosnu i proširila se na Hercegovinu. Matične knjige župa Trebinjsko-mrkanske biskupije najbolje pokazuju prave razmjere kuge koja je pogodila jugoistočnu Hercegovinu u razdoblju od 1814. do 1818. godine. Tako je iz matica umrlih Župe Ravno razvidno kako je prvi slučaj smrti od kuge na području te župe zabilježen 25. listopada 1814. godine. ${ }^{19}$ Epidemija se proširila iz zapadne Hercegovine gdje se u Župi Brotnjo pojavila 3. lipnja, ${ }^{20}$ a u Župi Studenci 3. kolovoza 1814. godine. ${ }^{21}$ Na područje Župe Ravno kuga je prenesena iz Stoca. Naime, i prvi i zadnji slučaj smrti od kuge, zabilježen u matice Župe Ravno, dogodio se u Stocu. Iako Stolac nije bio sastavnica Župe Ravno, tamo je od kuge umrlo i pokopano 27 župljana te

16 Denuncijacije Malom vijeću, sv. 3176/2, br. 120; 11. 3. 1795.; Goran Cvjetrinović, Karika obavještajne mreže Dubrovačke Republike; Kultura samozaštite - Denuncijacije Malom vijeću (17401799), doktorski rad, Dubrovnik, 2016., 66.

17 Denuncijacije Malom vijeću, sv. 3176/2, br. 121; 13. 3. 1795.; G. Cvjetinović, Karika obavještajne mreže Dubrovačke Republike, 66.

18 Denuncijacije Malom vijeću, sv. 3176/2, br. 122; 16. 3. 1795.; G. Cvjetinović, Karika obavještajne mreže Dubrovačke Republike, 66.

19 Matica umrlih župe Ravno (1804 - 1871), (dalje: MUŽR 1804 - 1871): 27. (Arhiv biskupije Mostarsko-duvanjske)

20 Robert Jolić, Stanovništvo Brotnja u tursko doba, Čitluk-Tomislavgrad, 2009., 290.

21 Vlado Pavičić, Rodovi Studenaca i Stubice, u: Župa Studenci u Hercegovini, Mostar, 2011. $108-190$. 
župe. Razlog tomu je što je veliki broj Popovaca tih godina bio na službi u Stocu. ${ }^{22}$ Tijekom petogodišnjeg razdoblja, od 1814. do 1818., na području Župe Ravno od kuge je umrla četvrtina tadašnjeg katoličkog stanovništva, 181 osoba. ${ }^{23}$ Najveći broj umrlih bio je 1815. godine, kad je od kuge umrla 101 osoba. ${ }^{24}$ Epidemija je najviše bila raširena u rubnim dijelovima župe, u naseljima Dubljani i Kotezi. ${ }^{25}$ Za razliku od zapadne Hercegovine, Župe Brotnjo, gdje je posljednji slučaj smrti od kuge bio 5. ožujka 1816., na području Župe Ravno epidemija je bila prisutna još dvije godine. Posljednja upisana smrt od kuge bila je u lipnju 1818. godine. ${ }^{26}$ Epidemija kuge se, osim na mortalitet, odrazila i na natalitet Župe Ravno. Tako je tijekom čitavog 19. stoljeća najmanji broj rođenja bio u jeku epidemije, 1816. i 1817. godine, kada je tijekom te dvije godine rođeno i kršteno tek po 13 djece. ${ }^{27}$

Na području druge župe Trebinjsko-mrkanske biskupije, Župe Gradac, od te epidemije umrlo je "samo“ 20 osoba. ${ }^{28}$ Tamo se epidemija pojavila tijekom siječnja 1815. godine, i to najprije u naselju Drijen, a tijekom veljače i ožujka proširila se na naselje Zelenikovac. U travnju je zahvatila naselje Hotanj, a zatim naselja Gradac i Dubravicu. Zadnji upis smrti od kuge na području Župe Gradac bio je 20. lipnja 1816. godine. $^{29}$

O toj velikoj epidemiji sačuvani su podatci i za ostale krajeve u Bosni i Hercegovini. Primjerice, u jajačkom kraju od te kuge umrlo je preko 2000 katolika, a u travničkome njih oko $4000 .^{30} \mathrm{Na}$ području zapadne Hercegovine epidemija je ostavila strašne posljedice. Gotovo je prepolovila stanovništvo Župe Brotnjo. Samo u dvije godine (1814. i 1815.) od kuge je umrlo 2214 osoba. ${ }^{31} \mathrm{U}$ Župi Studenci za vrijeme epidemije umrla je četvrtina tadašnjeg stanovništva, ${ }^{32}$

22 Ljubo Mićević pojasnio je razlog odlaska u Stolac: „...kada bi u staro doba izdalo polje, mnoge porodice iz Popova išle bi 'na prezimu' u Stolac i u Mostar, a manje u okolna mjesta Dalmacije. Karakteristično je da Popovci nijesu kretali na prezimu u Trebinje i Ljubinje, kao bliža mjesta, iako su tamo imali svojih aga i begova. Izgleda da tamo za njih nije bilo rada ni uslova za život." Vidi: Ljubo MićEvić, Život i običaji Popovaca, Beograd, 1952., 63.

23 To je bilo jedino razdoblje u kojem je kroz matice bila uočljiva epidemija kuge. To je bila zadnja kuga i na dubrovačkom području, prenesena je iz Hercegovine, točnije s područja Župe Ravno. Vidi: Tatjana BuklIJAš, Kuga: nastajanje identiteta bolesti, Hrvatska revija, sv. 2/2, Zagreb, 2002., 90 - 94.

24 Marinko Marić, Stanovništvo Popova u Hercegovini: Ravno, Zagreb-Dubrovnik, 2015., 148.

25 M. MARIĆ, Stanovništvo Popova u Hercegovini, 154.

26 MUŽR (1804-1871): 53.

27 M. MARIĆ, Stanovništvo Popova u Hercegovini, 122.

28 Antun Koncul, Od mora do Mramora. Stanovništvo Graca u Hercegovini, Zagreb-Dubrovnik, 2018., $152-153$.

29 A. Koncul, Od mora do Mramora, 153.

30 Srećko M. DžAJA, Katolici u Bosni i zapadnoj Hercegovini na prijelazu iz 18. u 19. stoljeće. Doba fra Grge Ilijića Varešanina (1783-1813), Zagreb, 1971., 102; R. Jolić, Zarazne bolesti u Hercegovini, 192.

31 R. Jolić, Stanovništvo Brotnja, 269 - 275.

32 V. PAvičić, Rodovi Studenaca i Stubice, 133. 
a u gradu Mostaru njih 3000. ${ }^{33}$ U čitavoj Bosni i Hercegovini kuga je usmrtila više od polovice tadašnjih katolika, dok za pripadnike ostalih vjera podatci nisu dostupni. Naime, na tom je području prije kuge, 1813. godine, živjelo 114391 katolika, a po svršetku kuge, 1818., njihov broj se smanjio na $50928 .{ }^{34}$

Ta se katastrofalna epidemija iz Hercegovine proširila i na dubrovačko područje, u mjesto Področje na Pelješcu, gdje je prvi slučaj smrti zabilježen 6. studenog 1815. godine. Epidemija je potpuno poharala to mjesto, preživio ju je samo trinaestogodišnji dječak. ${ }^{35}$ U Čepikućama, naselju Dubrovačkog primorja, smještenom neposredno uz granicu s Hercegovinom, kuga se pojavila 30. studenog 1815. godine. ${ }^{36}$ Tijekom te i sljedeće, 1816. godine na širem dubrovačkom području od kuge je umrlo stotinjak osoba. ${ }^{37}$ To je bila posljednja epidemija kuge koja je harala dubrovačkim područjem.

Epidemija kuge u dubrovačko je zaleđe uglavnom dolazila i širila se karavanskim putovima iz drugih dijelova Osmanskog Carstva, najčešće u zaraženoj robi koju su donosili vojnici ili trgovci. ${ }^{38}$ Tijekom, a posebno nakon epidemije redovita njezina pratilja bila je glad. „Uz kugu se pridruži još nemili gost - glad, od koje skapavaše siromašni narod, koji sada poče bježati po šumama, da se uzčuva od okuženih.“39 Naime, stanovništvo je od zaraze bježalo daleko od naseljenih mjesta, u šume i pećine, pa su polja u takvim neprilikama uglavnom ostajala neobrađena ili je već prispjela ljetina ostajala nepobrana jer je zbog kuge nije imao tko „žeti i hranu kupiti” 40

Za razliku od obližnjeg Dubrovnika gdje se nastojalo predvidjeti mogući izvor i smjer kretanja zaraze u bližem i daljem susjedstvu, u zaleđu sve do početka 19. stoljeća nije bilo organizirane protukužne zaštite. Ako bi je kojim slučajem i bilo, pokretana je tek nakon što bi se kuga pojavila i usmrtile prve žrtve. Epidemije se najčešće nisu mogle suzbiti zato što su mjere bile nepotpune i poduzimane prekasno, „kaskalo“ se za kugom umjesto da se djelovalo preventivno, previđajući

33 V. Bazala, Calendarium pestis, 84.

34 Dragutin Kamber, Stanje župa i duša apostolskog vikarijata u Bosni srebreničko-otomanskoj prema popisu izvršenom 1813., Franjevački vjesnik, XXXIX, br. 4, 1932., 57, 86 - 88, 112 - 113 ; Boris Jakov BARUN, Dušobrižnički rad biskupa fra Augustina Miletića (1763.-1831.), Umag, 1998. $192-193$.

35 N. VeKarić, Kuga u Čepikućama, 135.

36 N. VeKarić, Kuga u Čepikućama, 135.

37 N. VeKarić, Kuga u Čepikućama, 136 - 138.

38 V. Miović-Perić, Na razmeđu, 119; Rina Kralj-Brassard, Grad i kuga: Dubrovnik 1691. godine, Anali Zavoda za povijesne znanosti HAZU, sv. 54/1, Dubrovnik, 2016., 115 - 170.

39 Ignacij Strukić, Povjestničke crtice Kreševa i franjevačkoga samostana, Sarajevo, 1899., $102 ; \mathrm{R}$. Jolić, Stanovništvo Brotnja, 288.

40 J. BAltić, A. Zirdum, Godišnjak od dogadaja crkvenih, 61. 
mogući smjer kretanja zaraze. ${ }^{41}$ Tamošnje se stanovništvo u suzbijanju kuge koristilo svime i svačime. Nevolja nije birala sredstva pa je jedan od „lijekova“ bio i zmijski otrov. Drugi „lijek“ bio je tzv. terijak, neka vrsta napitka od 50 do 70 različitih sastojaka, među kojima je bilo i sitno nasjeckano meso zmije ljutice, smola drveća, analni sekret dabra, bilje i začini. Takvi napici uzrokovali su povraćanje, znojenje ili pražnjenje crijeva. ${ }^{42}$ Također, u borbi protiv kuge služilo se i čaranjima ili činjenjem "mađije po hudobi“ ${ }^{43}$ Kuga se pokušavala odagnati i prebacivanjem zaraze na susjedno područje. Primjerice, kad se 1647. godine kuga pojavila u Novom neki tamošnji stanovnici okuženu su robu prokrijumčarili na područje Trebinja i Vodovađe u Konavlima, vjerujući kako će tako kuga iz Novoga prijeći u ta mjesta. Dubrovački agent u Herceg Novom, Miho Kuvelić, upozoravao je i na podmetanje zaražene robe u rupčiću u blizini konavoskih sela Duba i Stravča. ${ }^{44}$

Umrli od kuge nisu sahranjivani u posvećenim grobljima, nego na izoliranim mjestima izvan njih. ${ }^{45}$ Takva je praksa bila i u susjednim župama na dubrovačkom području. ${ }^{46}$ Zaražene mrtvace često su pokapali i u zajedničke grobove jer je bilo važno što prije pokopati ih radi širenja zaraze. Nastojalo ih se dostojno pokopati, makar i u šumi gdje su umrli, premda ni to uvijek nije bilo moguće. Pravilo je bilo da se iskopa što dublja grobna jama, ali uslijed stihijskog pokapanja to često nije bilo moguće. Mrtvace su potezali kukama i tako ih prenosili u grob. Kao preventivnu zaštitu od širenja zaraze po njima su posipali živo vapno.

\section{DUBROVAČKE PROTUKUŽNE MJERE NA GRANICI SA ZALEĐEM}

Pojave epidemija zaraznih bolesti u zaleđu širila je strah od zaraze i na dubrovačko područje. Naime, zaraza se na dubrovačko područje najčešće širila iz zaleđa pa su Dubrovčani zbog toga bili jako oprezni na svaki spomen epidemije u

41 R. KRALJ-Brassard, Grad i kuga, 121.

42 Danica Božıć-BužAnčıć, Liječnici, kirurzi, lijekarnici, lijekovi u liječenju kuge u Dalmaciji u XVIII. stoljeću, Povijesni prilozi, sv. 16, Zagreb, 1997., 135 - 157; R. RAdoš, Namjesnik bosanskog ejaleta, 231.

43 Đuro Orlić, Kuga u Herceg-Novom 1648 godine, Srpski arhiv za celokupno lekarstvo, poseban otisak, 83, $1955 ., 121$.

44 Đ. Orlić, Kuga u Herceg-Novom, 118 - 121.

45 Postojala su posebna mjesta za okužene mrtvace. Primjerice, iz Ravnoga su svi umrli od kuge pokopani u zaseoku Plasna Glavica, a ne u seoskom groblju Kuklježak gdje su se pokapali ostali pokojnici koji nisu umrli od kuge. Vidi: M. MARIć, Stanovništvo Popova u Hercegovini, 148.

46 U Čepikućama su ih pokapali na njivama ispred kuća. Vidi: N. VEKARIć, Kuga u Čepikućama, 135 - 139. 
zaleđu. Komunikacija iz zaleđa prema Dubrovniku odvijala se svakodnevno pa je u slučaju epidemije bilo važno spriječiti njezino širenje na dubrovačko područje. Granica Dubrovačke Republike sa zaleđem bila je ujedno i granica između prostora u kojem su se vrlo revno provodile protuepidemijske mjere i s druge strane područja u kojem protukužnih mjera nije bilo, nego su se tamošnje vlasti uglavnom oslanjale na dubrovačke mjere. ${ }^{47}$

S obzirom na dotadašnja iskustva, obrana od kuge bila je sinonim opstanka grada i Republike. Dubrovačka vlast zato je poduzimala sve moguće mjere kako se zaraza iz zaleđa ne bi proširila na područje Republike. Dubrovčani su vrlo rano razvili dobru obavještajnu mrežu preko koje su dobivali vijesti o pojavama epidemija u zaleđu ${ }^{48}$ Primjerice, jedna od dužnosti poklisara harača bila je javljati o svakoj epidemiji koja bi se pojavila u zemljama kroz koje bi oni prolazili prilikom nošenja harača u Carigrad. Istu obvezu imali su dubrovački konzuli i agenti koji su bili na službama u dubrovačkom okruženju. Takve su informacije često omogućavale žurnu reakciju na pojavu prvih vijesti o kugi. Svrha svega toga bila je zaštita Republike, kako njezina stanovništva tako i njezine trgovine jer u slučaju pojave kužne robe njezina daljnja prodaja u zaleđe bila bi onemogućena. Zato su Dubrovčani, čim bi dobili takve informacije, strogo nadzirali brodove, robu i putnike koji su dolazili u Dubrovnik. Takve dojave često su slali njihovi pomorski kapetani. Tako je primjerice kapetan Ivan Vodopić 5. srpnja 1788. godine javio da je u Smirni s kapetanom Tomom Mitrovićem razgovarao o kugi koja je pogodila taj grad. Također, isti javlja da u Solunu od kuge dnevno umiru po tri osobe. ${ }^{49}$ Također, kapetan Tasović iz grčke Cisone javio je kako u tom gradu tri do četiri kuće dnevno zahvati kuga, ${ }^{50}$ a kapetan Ivan Falkonetti javljao je o kugi u Zanteu, Kefaloniji i Moreji. ${ }^{51}$

U razgranatu obavještajnu mrežu bili su uključeni i katolički svećenici u zaleđu, kuriri, trgovci, vojnici i stražari na granici te svi povjerljivi dubrovački

47 R. Kralj-Brassard, Grad i kuga, 121.

48 Dubrovačke su vlasti informacije o kugi dobivale i iz drugih dijelova Mediterana. Primjerice, dubrovački konzul iz Livorna slao je redovito vijesti Pomorskom uredu u Dubrovniku o stanju s bolestima u mediteranskim lukama, kako bi se Republika mogla na vrijeme pripremiti za eventualne epidemije. Opširnije vidi u: Ilija Mıтı́́, Konzulati i konzularna služba Dubrovnika, Dubrovnik, 1973.

49 Acta Sanctae Mariae Maioris, sv. 3176/1, br. 353; 5. 7. 1788. (Državni arhiv u Dubrovniku); G. Cvjetinović, Karika obavještajne mreže Dubrovačke Republike, 66.

50 Acta Sanctae Mariae Maioris, sv. 3176/1, br. 364; 12.11. 1788.; G. Cvjetinović, Karika obavještajne mreže Dubrovačke Republike, 66.

51 Acta Sanctae Mariae Maioris, sv. 3176/2, br. 34; 12. 10. 1791.; G. Cvjetinović, Karika obavještajne mreže Dubrovačke Republike, 66. 
građani..$^{52}$ Tako primjerice dubrovački agent u Novom Miho Kuvelić 1647. godine izvješćuje dubrovačku vlast da se kuga pojavila na području Trebinja i Novoga. ${ }^{53}$ Slične informacije javio je i Božo Glumac iz Novog Pazara. Po povratku u Dubrovnik Glumac je izvijestio dubrovačku vladu „kako je od više ljudi čuo da je u kući Rama Sedlara u tri dana od kuge umrla žena i dvije djevojčice te da su deset dana kasnije umrli i Ramo i njegov sinčić. Kugu je, navodi, u Novi Pazar donio jedan trgovac iz Strumice koji je na konju nosio duhan. Kada je iskrcavao teret, bio je pokraj Sedlarove kuće i Rama je zamolio da mu pomogne. Ovaj je to učinio, zarazio je sebe i potom četiri člana svoje

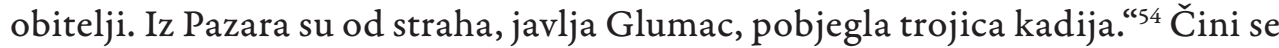
da je kuga u Novom Pazaru potrajala jer godinu dana nakon ove informacije i Vlaho Kunić, nakon boravka u tom gradu, javlja kako je mnogo osoba umrlo od kuge. Navodi kako su i u obližnjem mjestu Sjenici umrle 32 osobe. ${ }^{55}$

Konavoski knez Niko Saraca vladi je koncem 1769. javio da je od nekoliko pravoslavaca doznao kako se u području Sarajeva pojavila kuga, ${ }^{56}$ a vlada je učinila ono što i uvijek, na mjesto događaja uputila je povjerljivu osobu Ivana Ljubišu da se uvjeri u točnost informacije i razmjere bolesti. Ljubiša po povratku iz Sarajeva navodi „informo sam se u nekoga liječnika Koste Kršćanina je li koja nemoć u Sarajevu“. Doznao je kako je febra maligna zahvatila više ljudi, a da među oboljelima ima najviše onih koji su došli iz Rusije. Kod trojice od njih pojavile su se postime, otekline na vratu. Ljubiša navodi kako je jedan tražio da mu se oteklina proreže i da je iz nje potekla crna krv. Tri dana kasnije taj je čovjek umro. Druga dvojica imala su više sreće tog puta jer „parili su trave i ozdravili“. Više je ljudi u okolici Sarajeva umrlo od kuge, ali u samom gradu nije je bilo. Vraćajući se iz Sarajeva prema Dubrovniku, Ljubiša je prolazio kroz Mostar. Tamo je od više ljudi čuo kako je ista febra maligna došla i do Mostara. Rekli su mu kako je od nje umro jedan „momak kapetan od Stoca“ i da druga dvojica boluju u Stocu. To su

52 R. KRalj-Brassard, Grad i kuga, 121. U Državnom arhivu u Dubrovniku sačuvan je značajan broj dojava o epidemiji kuge u zaleđu, sumnjivim smrtima, kretanju osoba ili brodova bez valjanih zdravstvenih kartona i sl., na temelju čega su dubrovačke vlasti poduzimale određene sigurnosnoepidemiološke mjere. Opširnije vidi u: G. Cvjetinović, Karika obavještajne mreže Dubrovačke Republike.

53 D. OrLIć, Dubrovačke vijesti o epidemijama, 54.

54 Denuncijacije Malom vijeću, sv. 3175/1, br. 54; 1. 11. 1760.; G. Cvjetinović, Karika obavještajne mreže Dubrovačke Republike, 61.

55 Denuncijacije Malom vijeću, sv. 3175/1, br. 64; 30. 12. 1761.; G. Cvjetinović, Karika obavještajne mreže Dubrovačke Republike, 62.

56 Denuncijacije Malom vijeću, sv. 3175/1, br. 213; 29. 12. 1769.; G. Cvjetinović, Karika obavještajne mreže Dubrovačke Republike, 62. 
mu potvrdili i u Stocu te dodali kako je nekom Topuzoviću „bilo oteklo iza ušiju, ali da se pario s travom pa su mu otekline prošle." ${ }^{\text {(57 }}$

Božo Brbora, Pavo Šarilo i Boško Vragolov 13. svibnja 1782. godine podnijeli su detaljno izvješće o zdravstvenom stanju u zaleđu: „Izašli smo na Zupce, i đirali smo sva Sela od Zubaca, đe smo našli da se sva Sela miješaju jedno s'drugijem, i da je sve zdravo, govoreći svi Seljani, da je kuga otkada dospjela, i biće četiri Mjeseca dana. Izatega smo bili u Orahovu gdje smo našli, da je sve zdravo i također da su otvorene one dvije kuće Jelića, i ima osamnes dana, da su uljezli Čeljad ostala od Sela miješaju s'rečenijem kućam, anci smo mi odomadne ručali u rečenijem kućam zajedno s čeljadim od kuće, i rekli su Čeljad od kuće, da je dospjela veća kuga u Pridvorcu, u Rasovcu, i u Čičevu našli smo, da je sve zdravo, i da se sva Sela miješaju jedno s'drugijem; i također sve su kuće otvorene. Ufamo i mi, da po riječi od sve Čeljadi od Turskoga, koji su nam rekli, da je dospjela kuga."58

Za prikupljanje i analizu takvih informacija bili su zaduženi i pripadnici dubrovačkog Zdravstvenog ureda kojima je to bio glavni zadatak. ${ }^{59}$ Naime, zbog učestalih epidemija kuge koje su pogađale Dubrovnik tijekom prve polovice 14 . stoljeća, Dubrovčani su se prvi počeli organizirano suprotstavljati toj pošasti. Tako su još pred kraj 14. stoljeća organizirali vrlo učinkovit protuepidemijski sustav koji je zahvaljujući strogoj organizaciji pokušavao obraniti dubrovačko područje od širenja epidemija zaraznih bolesti. ${ }^{60}$ Okosnicu tog sustava činio je Zdravstveni ured osnovan 1390. godine koji je, između ostaloga, bio zadužen i za zaštitu od širenja epidemija na dubrovačko područje. ${ }^{61}$ Njegovi službenici zvali su se kacamorti. Birani su među vlastelom s rokom službe od godinu dana. Od 1390. imenovao ih je Senat. Kako bi se održao kontinuitet službe, primjenjivalo se tzv. preklapanje službi tako da su se dva nova kacamorta birala šest mjeseci prije isteka roka trajanja službe prethodnika. Tako su ranije izabrani službenici upućivali nove službenike u posao. ${ }^{62}$

Osnivanju takve službe najviše je pridonijela Crna smrt, epidemija kuge iz 1348., najtragičnija epidemija koja je zadesila tadašnji svijet. Usmrtila je veliki broj svjetskog stanovništva, a nije zaobišla ni Dubrovnik. U Dubrovniku je ostavila

57 Denuncijacije Malom vijeću, sv. 3175/2, br. 217; 10. 1. 1770.; G. CvJEtrinović, Karika obavještajne mreže Dubrovačke Republike, 62.

58 V. Miović-Perić, Na razmedu, 321 - 322.

59 Na primjer, odlukom iz srpnja 1796. bili su dužni svakih 15 dana izvještavati Senat o zdravstvenom stanju u Osmanskom Carstvu. Vidi: V. Miović-Perić, Na razmeđu, 119.

60 R. Kralj-Brassard, Grad i kuga, 117.

61 Zlata BlažınA-Tomić, Kacamorti i kuga. Utemeljenje i razvoj zdravstvene službe u Dubrovniku, Zagreb-Dubrovnik, 2007., 85.

62 Z. BlažINA-Tomić, Kacamorti i kuga, 104 - 105. 
strašne posljedice od kojih se dubrovačko stanovništvo zadugo nije oporavilo. ${ }^{63}$ U sljedećih četvrt stoljeća epidemija kuge zadesila je Dubrovnik još četiri puta, 1361., 1363., 1371. i 1374. godine. ${ }^{64} \mathrm{~S}$ obzirom na to da je "nevolja majka svake inovacije", tako učestale epidemije potaknule su dubrovačko Veliko vijeće da 27. srpnja 1377. godine donesu prvu odredbu o karanteni - Veniens de locis pestiferis non intret Ragusium vel districtum. ${ }^{65}$ Njome je bilo propisano da svi koji dolaze iz zaraženih krajeva ne smiju ući u Dubrovnik ni na njegov teritorij, a da prije toga ne provedu 30 dana u izolaciji na otoku Mrkanu ili Cavtatu. Trentina, tj. 30 dana „čišćenja“ kasnije je produženo na quarantinu, tj. u 40 dana. ${ }^{66}$ Uredbom o uspostavi karantene, kao načina borbe protiv kuge, Dubrovčani su bili prvi na Mediteranu koji su napravili takav vid zdravstvene zaštite. Time je Zdravstvena služba Dubrovnika započela djelovati 58 godina prije nego u Milanu, 96 godina prije nego u Veneciji i 137 godina ranije nego u Firenzi. ${ }^{67}$

Izolacija ili „karantena“ tih se godina, osim na Mrkanu i u Cavtatu, provodila i na susjednim otocima Bobari i Supetru. Godine 1430. Dubrovčani su karantenu premjestili bliže gradu, na Danče, gdje je izgrađen novi lazaret. Godine 1534. donijeli su odluku o izgradnji lazareta i na otoku Lokrumu, ali iz sigurnosnih razloga on nikad nije dovršen. ${ }^{68}$ Napokon su 1647 . godine izgrađeni lazareti na Pločama koji su zamijenili sve dotadašnje lazarete na dubrovačkom području. Dubrovačko rješenje "karantene“ razvilo se kao kompromis između potpunog prestanka prometa ljudi i roba, kako je često prakticirano u zapadnoj Europi, i djelomičnog prometa ljudi i roba bez obzira na kugu, kako se uglavnom postupalo u Osmanskom Carstvu, tako da je takav sustav trebao osiguravati osjetljivu ravnotežu između profita i rizika pomora. ${ }^{69}$

Osim blokade i stroge kontrole granice, dubrovačke su vlasti radi bolje kontrole napravile podjelu cijelog dubrovačkog područja, tj. Republike, na osam okruga. Centri tih okruga bili su u Mrcinama, Stravči, Brgatu, Kliševu,

63 Dubrovačke kronike donose podatke o 273 umrla vlastelina, 300 bogatih pučana i različit broj ostalih stanovnika, varijacija je od 1000 do 10 000. Vidi: Goran RaVANČIć, Vrijeme umiranja. Crna smrt u Dubrovniku 1348.-1349, Zagreb, 2010., 114 - 121.

64 Z. Blažina-Tomić, Kacamorti i kuga, 81.

65 V. Miović-Perić, Na razmeđu, 117; Ante MilošEvić, Dubrovačke karantene i lazareti: Fortuna critica et historica, u: Lazareti u Dubrovniku: početak karantenske službe u Europi, Zbornik radova, ur. Ante MilošEvić, Dubrovnik, 2018., 169.

66 Z. Blažina-Tomić, Kacamorti i kuga, 83; V. Miović-Perić, Na razmeđu, 118 - 119.

67 Z. BLAŽınA-Tomić, Kacamorti i kuga, $81-82$.

68 Vesna Miović, Život u karanteni: Lazareti na Pločama u vrijeme Republike, u: Lazareti u Dubrovniku: početak karantenske službe u Europi, Zbornik radova, ur. Ante MiLošEvić, Dubrovnik, 2018., 13.

69 R. Kralj-Brassard, Grad i kuga, 117 - 118. 
Čepikućama/Slanome, Ošlju, Stonu i na Pločama. U svaki centar postavljen je kacamort, a službenici saniteta nadgledali su lokalne puteve i nadgledali pastire sa stadima. ${ }^{70}$

S obzirom na geografski položaj Dubrovnika i stalnu prijetnju od širenja epidemija iz zaleđa, posebni sanitetski ured provodio je stroge protuepidemijske mjere zaštite i imao ovlasti prekršitelje novčano kažnjavati prema svom nahođenju. Ako prekršitelji ne bi platili kaznu u određenom roku, sanitetski službenici mogli su ih i tjelesno kazniti šibanjem, žigosanjem i odsijecanjem jednog uha. ${ }^{71}$ Primjerice, ostali su zapisani slučajevi kad je gradski stražar kažnjen paljenjem kose i brade jer je za novac puštao u grad siromahe iz kužnog zaleđa. ${ }^{72}$ Koliko su kazne mogle biti stroge zorno prikazuje i primjer vojnika koji je uhvaćen u prenošenju vune iz Hercegovine. On je bačen u okove, osuđen da na Placi bude triput „povučen na uže“, a potom da osam godina okovan vesla na stranoj galiji. $S$ obzirom na to da su liječnici prosudili da vojnik nije kadar izdržati tu kaznu, kazna je promijenjena u devet godina zatvora u morskoj tamnici ispod dvora sa zaključanim vratima. ${ }^{73}$ Osim što su tako kažnjavali prijestupnike, kazne su služile i kao opomena drugima da se pridržavaju protukužnih mjera. Primjerice, za posljednje epidemije kuge na dubrovačkom području, 1816. godine, Petar Delija iz Čepikuća „po naređenju vojnog starješine udaren ognjenim metkom, drugima za primjer izgubi život ".74 Tako su kacamorti na određen način predstavljali i sudsku i izvršnu vlast. ${ }^{75}$

Epidemije su znatno otežavale i trgovačku razmjenu Dubrovnika sa zaleđem, što nije odgovaralo ni jednoj ni drugoj strani. Sudeći po Knjigama karantene tijekom 18. stoljeća, trgovci su najčešće dolazili iz Sarajeva, Mostara, Trebinja, Novog Pazara, Ulcinja, Drača, Skadra i Smirne. Stizali su i iz mnogih drugih mjesta, najviše iz Bosne i Hercegovine, potom Hrvatske, Srbije, Crne Gore, Kosova, Albanije, Turske, Grčke, Bugarske, Malte, Makedonije, Mađarske, Sirije, Slovenije te iz Sjeverne Afrike. ${ }^{76}$ Iz zaleđa se uvozila sirova koža, vuna, vosak, stoka, žito i druge živežne namirnice, a s dubrovačkog područja prema zaleđu uglavnom se izvozila sol, usoljena riba, vino, voće, šećer i tkanine. Trgovina između pograničnih sela s obje strane dubrovačke granice bila je dopuštena dva

70 V. MIOviĆ-PERIĆ, Na razmedu, 120 - 122.

71 Risto Jeremić, Jorjo TADIĆ, Prilozi za istoriju zdravstvene kulture starog Dubrovnika, sv. 3, Beograd, 1940., 60; Z. BLAŽınA-Tomı́́, Kacamorti i kuga, 87.

72 T. BuKlijaš, Kuga: nastajanje identiteta bolesti, 93.

73 T. BuklıjAš, Kuga: nastajanje identiteta bolesti, 94.

74 N. VeKarić, Kuga u Čepikućama, 135 - 139.

75 Z. BlažInA-Tomić, Kacamorti i kuga, 104.

76 V. Miović, Život u karanteni, 27. 
dana u tjednu, i to na posebnim tržnicama ograničenog tipa. Pored redovite straže svako selo trebalo je odrediti dva stražara koja su to nadgledala. Roba na tim tržnicama bila je strogo ograničena i kontrolirana. Primjerice, maslo se moralo na licu mjesta pretopiti, perad, jaja, voće i povrće su se ispirali vodom, sir bi se „oprljio“ vatrom itd..."

Nakon zastoja uslijed epidemija trgovačka razmjena prva bi proradila. Kao i u ostalim dalmatinskim gradovima, u kriznim situacijama zbog epidemija granica se smjela prelaziti samo na točno određenim mjestima, tzv. kordonima. To su bili granični prijelazi koje je čuvala vojna posada. Kordoni su služili zdravstvenoj preventivi, da karantenskim i drugim mjerama spriječe moguće širenje epidemije. Uvođenje sanitarnih kordona značajno je poboljšalo i sustav zaštite od širenja epidemija na dubrovačko područje. Bilo je važno da se prva protuepidemijska kontrola obavi dalje od grada, na samoj granici Republike, a nakon toga da se trgovačka karavana, u slučaju sumnje u zarazu, pod strogim nadzorom stražara i zdravstvenih službenika sprovede do gradskog lazareta. ${ }^{78}$ Tako su primjerice za vrijeme epidemije kuge u zaleđu 1742. godine Dubrovčani na granicu postavili sanitarni kordon te zamolili stolačkog kapetana da usmjerava karavane i trgovce na točno određene granične prijelaze. Unatoč tomu jedan „domaći pravoslavni Vlah" ${ }^{\text {“79 }}$ prenio je kugu na dubrovačko područje pa je Senat 23. studenog te godine razmatrao prijedlog da se tri osobe iz zaražene kuće izoliraju u jedan badžafer. ${ }^{80}$ Prijedlog je tada odbijen, a donesena je odluka da se izolira prigradsko područje od kapelice sv. Križa iznad Posata do kuće Vicka Petrovića, uključujući i nju. ${ }^{81}$ Zbog toga je Senat naredio da se „svi Vlasi nastanjeni izvan izoliranog područja moraju preseliti u njega, a ako ne bude mjesta, treba ih zaključati u njihove kuće i postaviti stražare. Sve trgovine Vlaha treba zapečatiti, a Vlahe koji se nađu u njima sprovesti u izolaciju. Troškove Zdravstvenog ureda za tu operaciju u iznosu od 1001 dukata, bude li moguće, namirit će krivci za prodor kuge. ${ }^{\text {"82 }}$ Ono što je zanimljivo za ovu pojavu kuge je to što su Dubrovčani, umjesto da o kugi izvijeste sredozemne Zdravstvene urede, s kojima su inače stalno surađivali i razmjenjivali informacije o pojavi zaraze, pojavu kuge zatajili. Tako podatke

77 V. Miović-Perić, Na razmedu, 122.

78 Mirela Slu kan Altić, Povijest sanitarnih kordona i njihova uloga u razvoju dalmatinskih gradova, Ekonomska i ekohistorija: časopis za gospodarsku povijest i povijest okoliša, sv. 2/1, 2006., 55 - 64.

79 V. Miović, Život u karanteni, 33.

80 Ovo je bio uobičajeni naziv za dvorište Lazareta (badžafer ili babadžafer). Naziv je nastao po Baba Džaferu, zloglasnom istambulskom zatvoru koji je imao dvorište i nalazio se na morskoj obali. V. Miović, Život u karanteni, 16 - 17.

81 V. Miović, Život u karanteni, 33.

82 V. Miović, Život u karanteni, 33. 
o zarazi Tajništvo Republike nije upisalo u zdravstvene listove koje je izdavalo kapetanima brodova. Tako se „dubrovački trgovački nerv pokazao jačim od savjesti. Osim 1742., oni su i 1765. godine zatajili kugu. " ${ }^{\text {"3 }}$ Početkom sljedeće godine Senat je konstatirao da se „vratila vjera u obnovu zdravlja jer je prošlo 40 dana od smrti posljednjeg Vlaha te je donesena odluka da se na misi u katedrali i tijekom procesije sv. Vlaha laudom Te Deum zahvali djelovanju Božanskog Veličanstva što je spasio Grad od biča kuge “. ${ }^{84}$

Slična situacija ponovila se i tijekom svibnja 1747. godine kada su Dubrovčani ponovo na granici postavili sanitarni kordon i donijeli odluku o upućivanju u Lazarete. ${ }^{85}$ Ako bi se i posumnjalo na zarazu, kontumacijske mjere brzo bi spriječile njezino širenje jer bi pripadnici sanitetskog ureda izolirali sumnjivu kuću ili čak čitavo selo na 80 dana. ${ }^{86}$

Veliku reorganizaciju sanitarnih kordona proveli su Austrijanci početkom druge austrijske uprave, 1820. godine, kada je djelovalo posebno sanitarno povjerenstvo na čelu s bojnikom Taborovićem. Broj kordona u odnosu na kraj mletačkog razdoblja udvostručen je pa je 1821. godine u Dalmaciji duž granice s Bosnom i Hercegovinom bilo 505 stražarskih postaja u kojima je djelovalo 3279 vojnika ${ }^{87}$ Duž granice između dubrovačkog i hercegovačkog teritorija bilo je utvrđeno 56 postaja. ${ }^{88}$

Nisu uvijek svi osmanski podanici dragovoljno prihvaćali i poštivali protuepidemijske mjere koje je provodio dubrovački zdravstveni sustav. Primjerice, nisu poštivali kontumacijski propis o višednevnom boravku u karanteni u Lazaretima. Od sredine 18. stoljeća dubrovačke vlasti sve su se češće žalile da osmanski trgovci i putnici ne poštuju pravila karantene, nego noću provaljuju zaključana vrata lazareta, napadaju vojnike saniteta i bježe $s$ Ploča ${ }^{89} \mathrm{~S}$ obzirom na broj i učestalost sultanovih fermana i bujuruldija bosanskih namjesnikai hercegovačkih sandžakbega, razvidno je da su bosanskohercegovački osmanski dostojanstvenici agilno surađivali s Dubrovčanima kad se radilo o protukužnim mjerama. Naime, kako bi bar donekle zaštitili područje Bosanskog ejaleta od kuge, osmanski vlastodršci oslanjali su se u velikoj mjeri na dubrovačke protukužne mjere. Osoba koja je to provodila bio je neslužbeni konzularni osmanski predstavnik u Dubrovniku - emin dubrovačke skale. On je stolovao

83 V. Miović, Život u karanteni, 33.

84 R. RADoš, Namjesnik bosanskog ejaleta, 264.

85 R. RADoš, Namjesnik bosanskog ejaleta, 141.

86 V. Miović-Perić, Na razmeđu, 135 - 136.

87 M. Slukan Altić, Povijest sanitarnih kordona, 60.

88 Stjepan Ćosić, Dubrovnik nakon pada Republike (1808.-1848.), Dubrovnik, 1999., 186.

89 Vesna Miović, Dubrovačka Republika u spisima osmanskih sultana, Dubrovnik, 2005., 169, 171. 
na dubrovačkim Pločama, a bio je izravno odgovoran bosanskom beglerbegu, a beglerbeg Porti. ${ }^{90}$ Njemu su putnici koji su dolazili iz rizičnih krajeva morali potpisati potvrdu da se neće protiviti protuepidemijskim mjerama. Radilo se najčešće o bosanskim trgovcima i hadžijama koji su se vraćali s hodočašća iz Meke. ${ }^{91}$ Ovo je konkretan primjer kako su se osmanske vlasti, kroz osobu emina, oslanjale na dubrovačke protukužne mjere da zaštite Bosnu jer je i tamošnjim osmanskim vlastima bilo u interesu da putnici koji se vraćaju iz stranih zemalja prođu dubrovačku karantenu i tek nakon toga uđu u Bosnu. Protuepidemijskih propisa nisu se uvijek pridržavali ni mještani pograničnih sela s obje strane granice, nego su i jedni i drugi potkrijuć prelazili granicu. Ovi s dubrovačkog područja išli su nadničiti u Hercegovinu, a oni iz Hercegovine išli su krijumčariti robu na dubrovačko područje..$^{92}$ Ipak, unatoč takvim i sličnim događanjima protuepidemijske mjere na dubrovačkom području uglavnom su polučivale veliki rezultat. Vidljivo je to i iz broja epidemija koje su harale s drugu stranu granice, a koje se nisu proširile na dubrovačko područje.

\section{ZAKLJUČAK}

Dubrovnik je kroz prošlost bio povezan ekonomskim, socijalnim i drugim vezama sa svojim neposrednim i širim zaleđem. Donekle je bio i ovisan o tamošnjoj radnoj snazi s kojom je često popunjavao svoje nasušne potrebe. Trgovina kao glavna gospodarska grana odvijala se preko zaleđa u Bosnu i dalje, a s druge strane, s područja Osmanskog Carstva, roba je dolazila u Dubrovnik i dalje se brodovima prevozila širom svijeta. Zato je Dubrovčanima bilo važno ekonomsko, ali i socijalno stanje u zaleđu. Posebno im je bilo važno tamošnje zdravstveno stanje, $s$ obzirom na česte epidemije kuge s kojima su Dubrovčani kroz prošlost imali loša iskustva. Potaknuta tim iskustvima, dubrovačka vlast prva je utemeljila stroge protuepidemijske mjere kako bi spriječila širenje zaraze na svoje područje. Tako su još krajem 14. stoljeća organizirali izolaciju - karantenu, za sve došljake koji su dolazili u Dubrovnik iz sumnjivih krajeva. Također su ustrojili i Zdravstvenu službu koja se brinula o zdravstvenom stanju na području Republike, a ista je i osluškivala o zdravstvenom stanju u dubrovačkom okruženju te poduzimala potrebne mjere po tom pitanju. Tako

90 V. Miović, Dubrovačka Republika u spisima osmanskih sultana, 94 - 95.

91 V. Miović-Perić, Na razmedu, 123; V. Miović, Dubrovačka Republika u spisima osmanskih sultana, 95 .

92 V. Miović-Perić, Na razmeđu, 128 - 129. 
je granica između Dubrovačke Republike i Osmanskog Carstva istovremeno predstavljala granicu između strogo organiziranog zdravstvenog sustava i onog koji su nevolje tjerale da u određenim situacijama reagira trenutnim, uglavnom primitivnim protuepidemijskim mjerama. Osmanske vlasti u zaleđu bile su vrlo kooperativne i podržavale su dubrovačke protukužne mjere te su se u nedostatku svojih oslanjale na one dubrovačke. Tako su i službeno podržavali dubrovačku karantenu za svoje sunarodnjake koji bi se preko Dubrovnika vraćali u Bosnu i druge krajeve u Carstvu. Time su štitili svoje stanovništvo od moguće zaraze koju su mogli donijeti oni koji su se vraćali iz sumnjivih krajeva, primjerice $s$ hodočašća iz Meke. Naime, u zaleđu nije bilo organizirane zdravstvene zaštite ni organizirane službe koja bi se bavila zdravstvenim i protuepidemijskim mjerama. Osmansko Carstvo nije imalo zdravstveni sustav zaštite od kuge pa je zato smatrano stalnim izvorom zaraze. Kad bi se pojavila epidemija neke zarazne bolesti, a to je najčešće bila kuga, stihijski i sa zakašnjenjem poduzimale bi se najnužnije mjere. Zato su Dubrovčani poduzimali sve kako bi se eventualna zaraza zaustavila na samoj granici. Pri tom su primjenjivali vrlo stroge metode. Iako je u pograničnim područjima bilo teško kontrolirati provedbu protuepidemijskih mjera, jer su mještani s obje strane granice bili ovisni jedni o drugima, ipak su te mjere uglavnom polučivale značajne rezultate, što je vidljivo i po broju epidemija kuge u zaleđu koje se nisu proširile na dubrovačko područje. Dokaz toga je i to što je posljednja epidemija kuge u samom Dubrovniku bila krajem 17. stoljeća, 1691. godine, dok su se epidemije kuge u zaleđu pojavljivale sve do dvadesetih godina 19. stoljeća. 


\section{IZVORI I LITERATURA}

\section{IZVORI:}

Arhiv biskupije Mostarsko-duvanjske

Matica umrlih župe Ravno (1804 - 1871)

\section{LITERATURA:}

BALtić, Jako, Zirdum, Andrija, Godišnjak od događaja crkvenih, svjetskih i promine vrimena u Bosni, Sarajevo, 1991., 61 - 63.

BARUN, Boris Jakov, Dušobrižnički rad biskupa fra Augustina Miletića (1763.1831.), Umag, 1998.

BAtinić, Mijo Vjenceslav, Djelovanje franjevaca u Bosni i Hercegovini za prvih šest viekova njihova boravka, Zagreb, 1881. - 1887.

BAZALA, Vladimir, Calendarium pestis (II), Acta historica medicinae pharmaciae veterinae, sv. 2, Beograd, 1962., 72 - 87.

BENIĆ, Bono, Ljetopis sutješkog samostana, Sarajevo, 1979.

BlažInA-Tomić, Zlata, Kacamorti i kuga. Utemeljenje i razvoj zdravstvene službe u Dubrovniku, Zagreb-Dubrovnik, 2007.

Božıć-BužAnčıć, Danica, Liječnici, kirurzi, lijekarnici, lijekovi u liječenju kuge u Dalmaciji u XVIII. stoljeću, Povijesni prilozi, sv. 16, Zagreb, 1997., 135 - 157.

BuKlijaš, Tatjana, Kuga: nastajanje identiteta bolesti, Hrvatska revija, sv. 2/2, Zagreb, 2002., 90 - 94.

Cvjetinović, Goran, Karika obavještajne mreže Dubrovačke Republike; Kultura samozaštite - Denuncijacije Malom vijeću (1740-1799), doktorski rad, Dubrovnik, 2016.

Ćosić, Stjepan, Dubrovnik nakon pada Republike (1808.-1848.), Dubrovnik, 1999.

DžAJA, Srećko M, Katolici u Bosni i zapadnoj Hercegovini na prijelazu iz 18. u 19. stoljeće. Doba fra Grge Ilijića Varešanina (1783-1813), Zagreb, 1971.

HrabAK, Bogumil, Kužne radnje u Bosni i Hercegovini 1463 - 1800, Istorijski zbornik, sv. 2., 1981., 22 - 24.

HrABA K, Bogumil, Talasi kuge na bosanskohercegovačkom upravnom prostoru 1463 - 1800, Acta historica medicinae stomatologiae pharmaciae medicinae veterinae, sv. 29/1, Beograd, 1989., 19 - 36.

JANEKović-RöMER, Zdenka, Stranac u srednjovjekovnom Dubrovniku: Između prihvaćenosti i odbačenosti, Radovi Zavoda za hrvatsku povijest, sv. 26, Zagreb, 1993., 27 - 38. 
Jeremić, Risto, TADIĆ, Jorjo, Prilozi za istoriju zdravstvene kulture starog Dubrovnika, sv. 3, Beograd, 1940.

Jolić, Robert, Zarazne bolesti u Hercegovini u doba turske vladavine, Hercegovina, sv. 1/26, Mostar, 2015, 187 - 213.

JolıĆ, Robert, Stanovništvo Brotnja u tursko doba, Čitluk-Tomislavgrad, 2009.

KAmber, Dragutin, Stanje župa i duša apostolskog vikarijata u Bosni srebreničko-otomanskoj prema popisu izvršenom 1813., Franjevački vjesnik, XXXIX, br. 4, $111-121$.

KAPIDžIć, Hamdija, Stolac u XVIII vijeku, Slovo Gorčina, sv. 79, Stolac, 1997., $57-74$.

Koncul, Antun, Od mora do Mramora. Stanovnistvo Graca u Hercegovini, Zagreb-Dubrovnik, 2018.

KralJ-Brassard, Rina, Grad i kuga: Dubrovnik 1691. godine, Anali Zavoda za povijesne znanosti HAZU, sv. 54/1, Dubrovnik, 2016., 115 - 170.

Krešić, Milenko, Odnosi katolika jugoistočne Hercegovine $s$ muslimanima $i$ pravoslavnima u vrijeme osmanske vladavine - Od osmanskoga zauzeća do Bečkoga kongresa (1482. - 1815.), Zagreb, 2008.

Marić, Marinko, Stanovništvo Popova u Hercegovini: Ravno, ZagrebDubrovnik, 2015.

MićEvić, Ljubo, Život i običaji Popovaca, Beograd, 1952.

Milošević, Ante, Dubrovačke karantene i lazareti: Fortuna critica et historica, u: Lazareti u Dubrovniku: početak karantenske službe u Europi, Zbornik radova, ur. Ante Milošević, Dubrovnik, 2018., 167 - 201.

Miović, Vesna, Dubrovačka Republika u spisima osmanskih sultana, Dubrovnik, 2005.

Miović, Vesna, Život u karanteni: Lazareti na Pločama u vrijeme Republike, u: Lazareti u Dubrovniku: početak karantenske službe u Europi, Zbornik radova, ur. Ante Milošević, Dubrovnik, 2018., 13 - 50.

Miović-Perić, Vesna, Na razmeđu. Osmansko-dubrovačka granica (1667-1806), Dubrovnik, 1997.

Mitić, Ilija, Konzulati i konzularna služba Dubrovnika, Dubrovnik, 1973.

Orlić, Djuro, Dubrovačke vijesti o epidemijama u Bosni i Hercegovini u XVII vijeku, Gradja II, Sarajevo, 1956., 47 - 64.

Orlić, Đuro, Kuga u Herceg-Novom 1648 godine, Srpski arhiv za celokupno lekarstvo, poseban otisak, 83, 1955., 118 - 122.

Pavičıć, Vlado, Rodovi Studenaca i Stubice, u: Župa Studenci u Hercegovini, Mostar, 2011., 108 - 190. 
Radoš, Ruža, Namjesnik bosanskog ejaleta Ali-paša Hekimoglu (1736 - 1748) i Dubrovačka Republika, Zagreb, 2017.

Ravančić, Goran, Vrijeme umiranja. Crna smrt u Dubrovniku 1348.-1349, Zagreb, 2010., $114-121$.

Slukan Altić, Mirela, Povijest sanitarnih kordona i njihova uloga u razvoju dalmatinskih gradova, Ekonomska $i$ ekohistorija: ćasopis za gospodarsku povijest i povijest okoliša, sv. 2/1, 2006., 55 - 64 .

ST RU KIĆ, Ignacij, Povjestničke crtice Kreševa i franjevačkoga samostana, Sarajevo, 1899.

VeKarIĆ, Nenad, Kuga u Čepikućama 1815/6. godine, u: Zbornik Dubrovačkog primorja i otoka, sv. 2, Zbornik radova, ur. Zdravko Bazdan, 1988., 135 - 139.

Zirdum, Andrija, Filip Lastrić Oćevac 1700-1783: prilog kulturnoj povijesti Bosne i Hercegovine, Zagreb, 1982.

Zlatović, Stipan, Franovci države Presvetog Odkupitelja i hrvatski puk u Dalmaciji, Split, 1888. 
Marinko MARIĆ

\section{PLAGUE OUTBREAKS IN DUBROVNIK HINTERLAND DURING \\ THE 17TH, 18TH AND 19TH CENTURY AND DUBROVNIK BORDER ANTI-EPIDEMIC MEASURES}

\section{SUMMARY}

Dubrovnik has been repeatedly linked to its immediate hinterland. To a certain extent, it was dependant on the workforce in order to meet its pressing needs. Furthermore, its main economic branch, trade, extended over to the hinterland to Bosnia and even further. At the same time, the goods came from the Ottoman Empire to Dubrovnik, from where they were transported by ships. That is why the economic and social situation in the hinterland was very important for Dubrovnik. Special attention was paid to the health condition of the general population, given the frequent outbreaks of plague -wreaking tragedy among the people of Dubrovnik. Having learned from previous experiences and epidemics, the Dubrovnik authorities were the first, or among the first, to apply stringent anti-epidemic measures to prevent the spread of the infection to their area. Therefore, at the end of the 14th century, an isolation quarantine was set up for all visitors who came to Dubrovnik from suspicious and possibly affected areas. They created a health service to tend to the overall health of the population. In a way, the border between the Republic of Dubrovnik and the Ottoman Empire was also perceived in terms of an organized health system on the one side and "no system" on the other side of the border. There was no health nor an anti-epidemic service in the hinterland. When an epidemic of infectious disease occurred, which was often the plague, critical measures would be applied as a delayed response conducted in an uncontrolled and primitive manner entailing the burning of infected households, sometimes even with people inside the houses.

For this reason, Dubrovnik residents did everything in their power to stop the contagion from spreading at their border. In doing so, they applied rigorous methods and punished severely those who did not adhere to them. Implementing the guidelines in villages on either side of the border was challenging, given that locals on both sides depended on each other in some way. Still, the measures generally yielded significant results, which is also evident in the number of plague outbreaks in the hinterland which did not spread to the Dubrovnik area.

Keywords: the epidemic of plague, public health measures, the hinterland of Dubrovnik, Dubrovnik. 
